\title{
Article
}

\section{Blood glucose-lowering therapy in adults with type 2 diabetes}

\author{
Nuttall, Dilyse \\ Available at http://clok.uclan.ac.uk/21261/ \\ Nuttall, Dilyse ORCID: 0000-0002-0561-5229 (2016) Blood glucose-lowering \\ therapy in adults with type 2 diabetes. Nurse Prescribing, 14 (2). pp. 66-67. \\ ISSN 2052-2924
}

It is advisable to refer to the publisher's version if you intend to cite from the work. 10.12968/npre.2016.14.2.66

For more information about UCLan's research in this area go to http://www.uclan.ac.uk/researchgroups/ and search for < name of research Group>.

For information about Research generally at UCLan please go to http://www.uclan.ac.uk/research/

All outputs in CLoK are protected by Intellectual Property Rights law, including Copyright law. Copyright, IPR and Moral Rights for the works on this site are retained by the individual authors and/or other copyright owners. Terms and conditions for use of this material are defined in the policies page.

\section{CLoK}

Central Lancashire online Knowledge www.clok.uclan.ac.uk

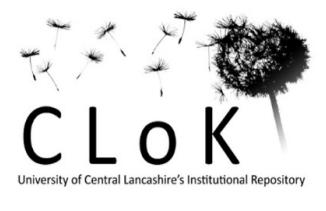




\section{Calculation Skills: Blood Glucose Lowering Therapy in Adults with Type 2 Diabetes}

Approximately $90 \%$ of cases of diabetes are of Type 2 diabetes, where the body either becomes resistant to the effect of the insulin produced or produces inadequate amounts of insulin (Public Health England, 2014). Incidence of diabetes is rising, with 6\% (2.7million) of people aged 17 years or over in England in 2013, diagnosed with diabetes. A range of complications are associated with type 2 diabetes, including retinopathy, neuropathy, nephropathy and cardiovascular disease (Diabetes UK, 2015). As such, the effective management of type 2 diabetes is essential and should be individualised and underpinned by patient education (National Institute of Health and Care Excellence [NICE], 2013).

\section{Question 1}

Based on the incidence figures above, what is the total population of people aged 17 years and over, on which these figures are based?

\section{Question 2}

Charlotte is a 46 year old administrator who was diagnosed with type 2 diabetes 10 months ago. Although classed as obese on diagnosis, she was receptive to the support given to assist in her weight loss and has maintained a normal weight for the past 4 months. However, despite making appropriate lifestyle changes, her $\mathrm{HbA} 1 \mathrm{c}$ continues to range from $48-50 \mathrm{mmol} / \mathrm{mol}$. It is agreed that she should commence drug therapy, which based on NICE (2015) guidance will be standard-release metformin.

(i) The regime agreed is $500 \mathrm{mg}$ daily for 1 week, $500 \mathrm{mg}$ twice daily for one week and then $500 \mathrm{mg}$ three times daily thereafter. How many $500 \mathrm{mg}$ tablets will need to be prescribed to complete the first 7 weeks of treatment?

(ii) Metformin tablets are available in two pack sizes: 28-tab pack costing 87p and 84-tab pack costing $£ 1.00$. What will be the most cost-effective pack combination for this 7 week treatment period (assuming packs will not be split) whilst prescribing the least number of tablets over the required amount?

\section{Question 3}

Roger is a 31 year old retail manager who was diagnosed with type 2 diabetes 5 months ago. He has been unable to tolerate standard-release metformin and following an unsuccessful trial of modified-release metformin, it is agreed that sulfonylurea treatment is appropriate.

\begin{tabular}{|c|c|c|}
\hline Sulfonylurea & Dose & Cost \\
\hline Glibencamide & $\begin{array}{l}5 \mathrm{mg} \text { daily adjusted according to } \\
\text { response, max. } 15 \mathrm{mg} \text { daily }\end{array}$ & $\begin{array}{l}2.5 \mathrm{mg} 28 \text {-tab pack } £ 18.50 \\
5 \mathrm{mg} 28 \text {-tab pack } 97 \mathrm{p}\end{array}$ \\
\hline Gliclazide & $\begin{array}{l}40-80 \mathrm{mg} \text { daily adjusted according to } \\
\text { response up to } 160 \mathrm{mg} \text { single dose, } \\
\text { max. } 320 \mathrm{mg} \text { daily in divided doses }\end{array}$ & $\begin{array}{l}\text { 40mg 28-tab pack } £ 3.36 \\
80 \mathrm{mg} 28 \text {-tab pack } 11.04 \\
80 \mathrm{mg} 60 \text {-tab pack £2.23 }\end{array}$ \\
\hline Glimepiride & $\begin{array}{l}1 \mathrm{mg} \text { daily adjusted according to } \\
\text { response, max. } 4 \mathrm{mg}\end{array}$ & $\begin{array}{l}1 \mathrm{mg} 30 \text {-tab pack } £ 1.20 \\
2 \mathrm{mg} 30 \text {-tab pack } £ 1.12 \\
3 \mathrm{mg} 30 \text {-tab pack } £ 7.25 \\
4 \mathrm{mg} 30 \text {-tab pack } £ 1.33\end{array}$ \\
\hline Glipizide & $\begin{array}{l}2.5-5 \mathrm{mg} \text { daily, adjusted according to } \\
\text { response up to } 15 \mathrm{mg} \text { single dose, max. } \\
20 \mathrm{mg} \text { in divided doses }\end{array}$ & 5mg 56-tab pack £5.36 \\
\hline Tolbutamide & $0.5-1.5 \mathrm{~g}(\max .2 \mathrm{mg})$ in divided doses & 500mg 28-tab pack £22.64 \\
\hline
\end{tabular}

Use the data presented in the table to answer the following questions. 
(i) If Roger is prescribed Glibencamide $5 \mathrm{mg}$ daily for 4 weeks and this was increased to a maintenance dose of $7.5 \mathrm{mg}$ daily, how many tablets will he have taken in a 16 week period (assuming a tablet combination which requires the least number of tablets to be taken)?

(ii) If Roger's prescribed regime was Tolbutamide at a maintenance dose of $1.5 \mathrm{mg}$ daily (divided into three equal doses), how many packs (un-split) would he need for the period $1^{\text {st }}$ March 2016 to $31^{\text {st }}$ July 2016 ?

(iii) If Roger is prescribed Glimepiride with the following regime, assuming he has only $1 \mathrm{mg}$ tablets available to him in the first 3 weeks and $3 \mathrm{mg}$ tablets thereafter, what will be the cost of this 14 week treatment (assuming packs are not split)?

Weeks 1 \& 2 - $1 \mathrm{mg}$ daily

Week 3 - 2 mg daily

Weeks 4-14 (inclusive) - 3mg daily

(iv) What would be the cost difference for 2 months (assuming 30 days per month) treatment with a daily $160 \mathrm{mg}$ single dose of Glicazide or a daily dose of Glipizide $15 \mathrm{mg}$ ? 


\section{Answers}

\section{Question 1}

Based on the incidence figures above, what is the total population of people aged 17 years and over, on which these figures are based?

$6 \%=2700,000$

$1 \%=2700,000 \div 6=450,000$

$100 \%=450,000 \times 100=45,000,000$

Total population is 45 million

\section{Question 2}

(i) How many 500mg tablets will need to be prescribed to complete the first 7 weeks of treatment?

Week 1: 1 tablet per day $=7$ tablets

Week 2: 2 tablets per day $=14$ tablets

Week $3-7: 3$ tablets per day $=21$ tablets $\times 5$ weeks $=105$ tablets

Total: $7+14+105=126$

(ii) What will be the most cost-effective pack combination for this 7 week treatment period (assuming packs will not be split) whilst prescribing the least number of tablets over the required amount?

Required tablets $=126$

Possible combinations:

$5 \times 28$ pack (total 140 tablets) $=5 \times 87 p=£ 4.35$

$1 \times 84$ pack $+2 \times 28$ pack $($ total 140 tablets $)=£ 1.00+(2 \times 87 p=£ 1.74)=£ 2.74$

$2 \times 84$ pack (total 168 tablets) $=£ 2.00-$ this is the most cost-effective .

\section{$\underline{\text { Question } 3}$}

(i) If Roger was prescribed Glibencamide $5 \mathrm{mg}$ for 4 weeks and this was increased to a maintenance dose of $7.5 \mathrm{mg}$, how many tablets will he have taken in a 16 week period (assuming a tablet combination which requires the least number of tablets to be taken)?

$1^{\text {st }} 4$ weeks $=1(5 \mathrm{mg})$ tablet daily $\times 28$ days $=28$ tablets

Weeks $5-16=(1 \times 5 \mathrm{mg}$ tablet $+1 \times 2.5 \mathrm{mg}$ tablet $) \times 84$ days $=2 \times 84=168$ tablets

Total tablets $=28+168=196$ 
(ii) If Roger's prescribed regime was Tolbutamide at a maintenance dose of $1.5 \mathrm{mg}$ daily (divided into three equal doses), how many packs (un-split) would he need for the period $1^{\text {st }}$ March 2016 to $31^{\text {st }}$ July 2016 ?

Number of days $=31+30+31+30+31=153$ days

Tablets per day $=3$

Total tablets required $=153 \times 3=459$

Packs required $=459 \div 28=16.4=17$ un-split packs

(iii) If Roger is prescribed Glimepiride with the following regime, assuming he has only $1 \mathrm{mg}$ tablets available to him in the first 4 weeks and $3 \mathrm{mg}$ tablets thereafter, what will be the cost of this 14 week treatment (assuming packs are not split)?

Weeks 1 \& 2 - $1 \mathrm{mg}$ daily

Week 3 - 2mg daily

Weeks 4-14 (inclusive) - 3mg daily

Weeks $1 \& 2=141 \mathrm{mg}$ tablets + Week $3=141 \mathrm{mg}$ tablets $=28$ tablets $($ so $1 \times 30$-tab pack $)=$ $£ 1.20$

Weeks $4-14=1 \times 3 \mathrm{mg}$ tablet $\times 77$ days $=77$ tablets (so $3 \times 30$-tab pack)

$3 \times £ 7.25=£ 21.75$

Total cost $1.20+21.75=£ 22.95$

(iv) What would be the cost difference for 2 months (assuming 30 days per month) treatment with a daily $160 \mathrm{mg}$ single dose of Glicazide or a daily dose of Glipizide $15 \mathrm{mg}$ ?

Glicazide:

Daily dose: $160 \mathrm{mg}=2 \times 80 \mathrm{mg}$ tablets

60 days treatment $=2 \times 60=120$ tablets

Packs required $=120 \div 60$-tab pack $=2$

Cost $=2 \times £ 2.23=£ 4.46$

Glipizide:

Daily dose: $15 \mathrm{mg}=3 \times 5 \mathrm{mg}$ tablets

60 days treatment $=3 \times 60=180$ tablets

Packs required $=180 \div 56$-tab pack $=3.2$ (4 un-split packs)

Cost $=4 \times £ 5.36=£ 21.44$

Cost difference $=21.44-4.46=£ 16.98$

\section{References}

Diabetes UK (2015) Diabetes Complications. Available online at: https://www.diabetes.org.uk/Guide-to-diabetes/Complications/

Joint Formulary Committee (2015) British National Formulary 69, London: BMA \& RPSGB

National Institute of Health and Care Excellence [NICE] (2015) Type 2 Diabetes in Adults:

Management, NG28. Available online at: https://www.nice.org.uk/guidance/ng28

Public Health England (2014) Adult Obesity \& Type 2 Diabetes, London: PHE Publications

Dilyse Nuttall 